\title{
WIRAUSAHA KOPERASI SISWA DI SEKOLAH
}

\author{
Mamik Oktaviana \\ Program Studi Pendidikan Guru Sekolah Dasar \\ Fakultas Keguruan dan Ilmu Pendidikan \\ Universitas Nahdlatul Ulama Sidoarjo
}

\section{Email: mamikvialisca@gmail.com}

\section{Pengantar}

Pada zaman sekarang dan zaman yang akan datang, paradigma layanan terhadap pendidikan harus bisa dirubah dan lebih dikembangkan bedasarkan yang diterapkan oleh Pemerintah. (Arifin, 2007) memaparkan bahwa yang mana pengembangan pendidikan yang awalnya yaitu teacher center (guru menjadi pusatnya) menjadi child centered (siswa mencari pengetahuan sendiri), dari subject mathod curriculum menjadi competence base curriculum, dan dari exclusive segregative educational menjadi inclusive education process. Jadi, dari perkembangnya zaman paradigma pendidikan harus bisa dirubah atau lebih dikembangkan lagi bedasarkan yang telah ditetapkan atau diterapkan oleh Pemerintah. (Koentjaraningrat, 1982) mengemukakan bahwa seluruh proses layanan di setiap pendidikan harus diorientasikan pada pemberdayaan siswa bedasarkan dengan keberagaman potensinya masing-masing siswa. Jadi, seluruh proses yang ada pada layanan pendidikan harus diorientasikan bedasarkan keberagaman potensi yang dimiliki oleh masing-masing siswa. Kunci dalam proses pelayanan pendidikan anak termasuk salah satunya proses pembelajaran siswa disekolah adalah "membentuk keterampilan jiwa atau sikap positif mental pada siswa", karena terbentuknya sikap mental positif pada peserta didik atau siswa yang dapat membantu para peserta didik untuk mendapatkan kesuksesannya.

Jadi, mengapa perlu sikap mental wirausaha siswa di sekolah melalui kopsis sekolah harus ditumbuhkan dengan baik dan tepat. Karena setiap peserta didik atau para individu siswa harus membangun sepanjang usia hidupnya dengan prinsip yang harus selalu berprestasi secara akedemik ataupun non-akademik dan berkarya untuk dapat meraih banyak kesuksesan dalam hidup. Maka dari itu wirausaha pendidikan khususnya pada mental para siswa harus dibangun dilingkungan sekolah, salah satunya melalui koperasi sekolah (kopsis) agar siswa dapat memanfaatkan usia 
hidupnya supaya bisa terus berkarya dan akan mengantarnya untuk meraih kesuksesan bedasarkan potensi yang dimilikinya.

\section{Dasar Konsep Mengenai Wadah OSIS Di Suatu Pendidikan}

OSIS merupakan singkatan dari Organisasi Siswa Intra Sekolah. Jadi, OSIS adalah salah satu wadah organisasi bagi siswa di sekolah dan lembaga kursus-kursus yang lain. OSIS memiliki pembina yaitu kepala sekolah, tenaga kerja kependidikan dan salah satunya guru yang akan bertanggung jawab terhadap pembinaan dan mengembangkan wadah organisasi OSIS di sekolah dan kursus-kursus lainnya tersebut. (Departemen P dan K, 1985) OSIS dibentuk karena untuk meningkatkan peran siswa dalam menjaga dan membina sekolah sebagai wiyatamandala, melatih siswa dalam berorganisasi dengan baik, memantapkan dalam menunjang pencapaian terdahap kurikulum pada satuan pendidikan yaitu dengan menunjang ekstrakurikuler sekolah, meningkatkan apresiasi dan penghayatan seni budaya, menumbuhkan sikap berbangsa dan bernegara dengan menjunjung tinggi nilai-nilai Pancasila dan UUD 1945, dan salah satunya adalah untuk meningkatkan ketaqwaan kepada Tuhan Yang Maha Esa. Jadi, tujuan dibentuknya OSIS yaitu salah satu untuk meningkatkan peran siswa dalam menjaga dan membina seolah yang tentunya dapat menumbuhkan sikap cinta tanah air dan untuk meningkatkan ketaqwaan kepada Tuhan Semesta Alam. Peran OSIS sangat dibutuhkan di sekolah dan lembaga kursus lainnya. Pengusus OSIS dilantik oleh kepala sekolah di sekolah dan kursus-kursus lain untuk jangka periode terbatas dan harus mengantongi pengesahan dari kepala sekolah selaku penanggung jawab disekolah. Proses pemilihan calon OSIS yaitu pada saat memasuki tahun ajaran baru yang mana telah ada pengesahan dari pembina OSIS salah satunya adalah kepala sekolah yang kemudian dilakukan Latihan Dasar Kepemimpinan Siswa yang biasa disebut dengan LDKS. Setelah itu dilakukannya pemilihan ketua OSIS dan wakilnya yang kemudian seluruh warga sekolah memilih hak suaranya terhadap OSIS yang sudah terpilih setelah pelaksanaan LDKS.

Dasar konsep menegnai OSIS dan pembinaan kesiswaan yang dapat dilaksanakan oleh kepala sekolah, ketenaga kerjaan dan guru terhadap peserta didik dalam suatu wadah organisasi OSIS yang mana menyangkut ke 'delapan bidang' secara integral. (Departemen P dan K, 1985) mengungkapkan bahwa keputusan yang telah di sahkan oleh Menteri Pendidikan dan Kebudayaan nomor 0461/ U/ 1984 merumuskan mengenai pembinaan kesiswaan yang menyangkut ke delapan bidang 
atau aspek, yaitu kemudian dilaksanakan dalam bentuk delapan Sekretaris Bidang (Sekbid), yaitu: (1) Sekbid ketaqwaan terhadap Tuhan Yang Maha Esa, (2) Sekbid dalam kehidupan berbangsa dan bernegar, (3) Sekbid pendidikan dalam bela negara, (4) Sekbid budi pekerti luhur dan karakter jiwa, (5) Sekbid berorganisasi, pendidikan politik dan kepemimpinan, (6) Sekbid ketrampilan dan kewirausahaan, (7) Sekbid kesegaran jasamani dan daya kreasi; dan (8) Sekbid persepsi, apresiasi dan kreasi seni.

\section{Wirausaha Pendidikan Dengan Menggunakan Kopsis Sekolah}

Aspek berwirausaha yang mana telah di implementasikan pada wirausaha pendidikan dengan melalui koperasi siswa (Kopsis) di lembaga pendidikan. Dalam pembentukan kopsis di sekolah mempunyai fungsi bagi siswa di satuan pendidikan yaitu untuk mendidik dan melatih peserta didik untuk mengembangkan potensi kewirausahaan dengan potensi dan keinginan yang sudah dimiliki siswa, dan untuk melatih dan mendidik siswa dalam memanajemen kopsis, terutama dalam pemberian terhadap proses layanan pendidikan yang terbaik terhadap berbagai macam kebutuhan siswa berkaitan dengan kelancaran proses pembelajaran di sekolah.

Pada hakikatnya kopsis yang ada dilingkungan satuan pendidikan tidak semata-mata untuk memfasilitasi berbagai kebutuhan material yang dibutuhkan oleh peserta didik atau siswa dalam pelaksanaan belajar di satuan pendidikan dan kursus-kursus lainnya, tetapi wirausaha pendidikan melalui kopsis ini harus bisa "melatih dan mengarahkan peserta didik dalam menumbuhkan prospek ke depan mengenai kewirausahaan", yang begitu dibutuhkan peserta didik dalam memproses kehidupan untuk kedepannya. Urgensi pengembangan wirausaha siswa sangat berpotensi karena kopsis di sekolah memiliki kegunaan yang sangat penting untuk memproses kewirausahaan pendidikan untuk peserta didik, jadi pengurusan atau manajemen terhadap kopsis disekolah tentunya harus dapat dilaksanakan dan dimanfaatkan dengan sebaik mungkin, dan benar-benar berperan aktif untuk sarana pelatihan atau praktik bagi peserta didik untuk proses mengembangkan sikap mental pendidikan kewirausahaannya. Koperasi sekolah (Kopsis) dibentuk didalam lingkungan sekolah untuk menunjang dalam segi kebutuhan siswa dan terutama melatih diri siswa untuk berwirausaha. 
Pembina OSIS harus benar-benar memfokuskan konsep penting dalam proses melatih dan membimbing peserta didik untuk mengembangkan prospek pendidikan kewirausahaan di satuan pendidikan, diantaranya:

Pertama, membangun sikap mental berwirausaha siswa adalah sangat sentral di dalam peran sekolah.

Kedua, tujuan dalam pembinaan dan pengembangan serta menerapkan pendidikan kewirausahaan siswa harus benar-benar dilaksanakan dengan cara bertahap dengan penyebaran konsep terhadap pembinaan siswa untuk berwirausaha di setiap pendidikan dan kursus-kursus lainnya, menerapkan serta mengembangkan program kewirausahaan, dan mengembangkan tenaga kependidikan dalam program paket kewirausahaan siswa.

Ketiga, tujuan dalam mempersiapkan peserta didik untuk memiliki sikap mental dalam berwirausaha untuk proses pembelajaran secara aktif, efektif, kreatif dan tentunya inovatif didalam kelas.

Keempat, pendidikan kurikulum formal, artinya di setiap satuan pendidikan harus memasukkan pendidikan kewirausahaan pada peserta didik dengan tepat agar siswa mengerti tentang dunia wirausaha dalam pendidikan.

Kelima, membangun pendidikan watak kewirausahaan pada diri setiap siswa oleh guru, dalam proses pembelajaran ataupun dalam tempat membina serta mengembangkan wirausaha pendidikan melalui koperasi siswa (Kopsis).

Keenam, menunjang pengembangan wirausaha pendidikan siswa di sekolah dengan cara memperkuat program institusi pendidikan kewirausahaan yaitu melalui Kopsis sebanyak-banyaknya dan membentuk dan mengembangkan program pendidikan kewirausahaan di suatu lembaga koordinasi pembinaan kewirausahaan.

Ketujuh, organisasi dan pengevaluasian kewirausahaan bagi peserta didik dengan cara pembelajaran praktik dengan menggunakan wirausaha pendidikan kopsis disekolah, bahwa pelaksanaan kegiatan tersebut pada sekretaris di bidangnya tersendidri yaitu bidang kewirausahaan yang dilaksanakan dalam bentuk kegiatan koperasi siswa (Kopsis). 


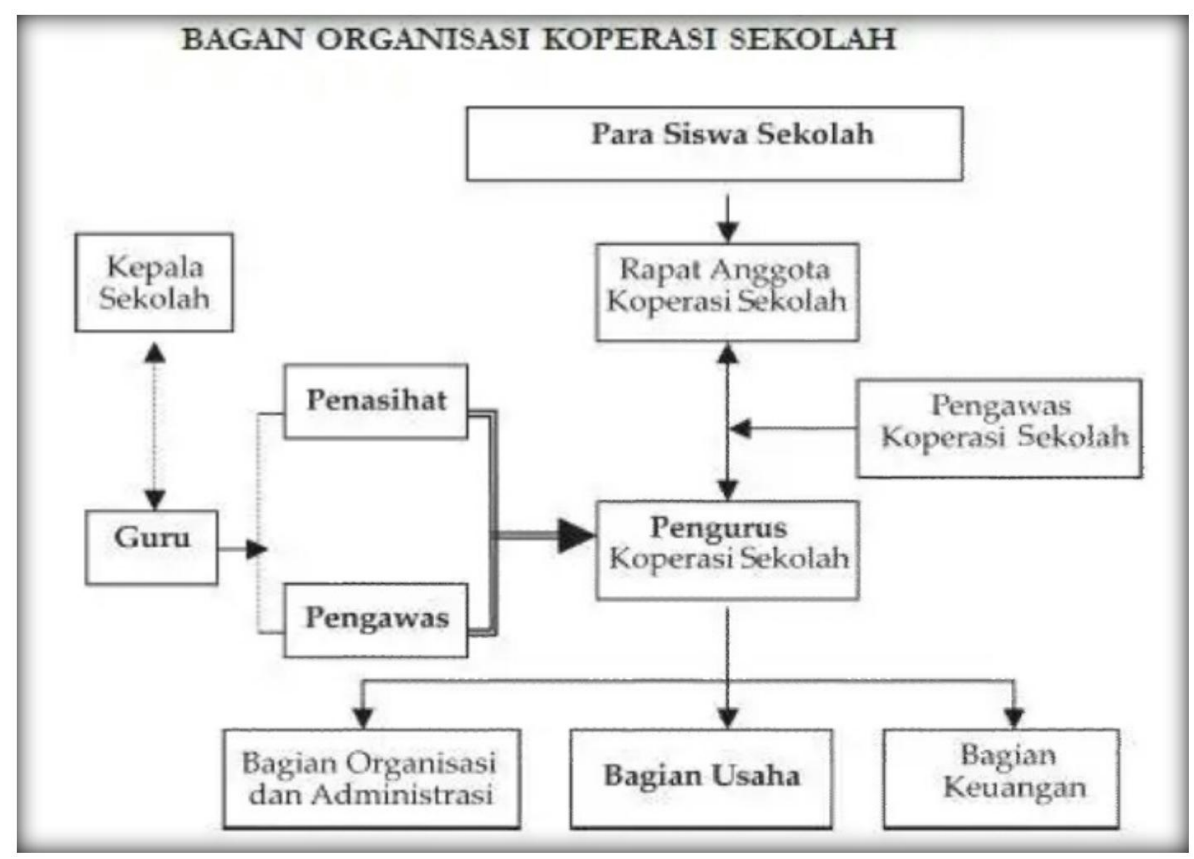

Gambar 1 : Bagan Organisasi Kopsis Sekolah bangkusekolah.com (Desember 6, 2015) 


\section{Penutup}

Program pendidikan kewirausahaan sangat penting untuk peserta didik di satuan pendidikan, dan pembinaannya dapat dilakukan dengan cara bertahap, proses pendidikan kewirausahaan peserta didik yang paling aktif di sekolah adalah pemberdayaan koperasi siswa (Kopsis), oleh karena itu pengaturan koperasi siswa di sekolah perlu dikelola dengan baik dan harus benar-benar dapat berfungsi untuk wadah pelatihan bagi para peserta didik untuk menumbuhkan jiwa kewirausahaannya. Konsep penting yang perlu diperhatikan dalam pembinaan dan pengembangan wirausaha pendidikan siswa di sekolah ada tujuh (sebagaimana yang telah diuraikan di atas).

\section{Daftar Pustaka}

Arifin, (2007). "Problematika SDM Guru Dalam Penerapan KTSP (Sebuah renungan Mencari Jalan Keluar). Jurnal Media, Nomor 08 / Th. XXXVII/ Oktober 2007. Kanwil Pendidikan dan Kebudayaan Propinsi Jawa Timur. Surabaya.

Koentjaraningrat, (1982). Kebudayaan, Mentalitas dan Pembangunan. Penerbit PT. Gramedia. Jakarta.

Departemen P dan K. (1985). Penanda Pelaksanaan OSIS. Dirjen Pendidikan Dasar dan Menengah. Direktorat Pembinaan Kesiswaan. Jakarta.

Departemen P dan K. (1985). Tuntunan Pembinaan Kewiraswastaan Bagi Peserta Didik. Dirjen Pendidikan Dasar dan Menengah. Direktorat Pembinaan Kesiswaan. Jakarta.

Yuniarti, D., Kautsari, M. F., Sholichah, F., Purnomo, A., \& Rosyidah, E. (2017). SMP SMA Al-Amin Ponpes Bahrul Hidayah Serahkan Pada Allah Ta'ala. In Wirausaha Pendidikan Indonesia (jilid 1). Sidoarjo: Unusida Press. http://bit.Iy/didiana1

Asitah, N., Usmawati, D.Z, Rosyidah, E., \& Purnomo, A. (2017). MI Hasyim Asy'ari Ilmu Harus Terus Mengerus. In Wirausaha Pendidikan Indonesia (jilid 2). Sidoarjo: Unusida Press. http://bit.Iy/sitanur1 
Sholichah, S. A., Istiqomah, A., Rosyidah, E., \& Purnomo, A. (2017). MI Darun Najah Berfikir Berkarya Berdzikir. In Wirausaha Pendidikan Indonesia (jilid 3). Sidoarjo: Unusida Press. http://bit.Iy/ichasiti1

Purnomo, A. (2017, December 5). Pengertian Edupreneur. http://doi.org/10.17605/OSF.IO/J3BCR http://osf.io/preprints/inarxiv/8fnu6/

Irawan, D. E., Purnomo, A., Sutiksno, D. U., Abraham, J., Alamsyah, A., Saputra, D. H., Tjokorda, J., Rosyidah, E. (2018). Kajian Pendidikan Tinggi IDR Untuk DPR RI dan Ristek Dikti 2018. Bandung: ITB Press. http://bit.Iy/2GseU0x 